\title{
The Social Value of Filmed Arts Lives
}

\author{
By A. Mary Murphy
}

Spring 2004 Issue of KINEMA

\section{MODEL LIVES: THE SOCIAL VALUE OF FILMED ARTS LIVES}

Film has developed thus far as a medium either for entertainment or education, but seldom for both at once. The problem has been, not that educational entertainment is oxymoronic, but rather the limited vision of filmmakers. Biographical film has the generic potential to be a meeting place for the documentary demands of scholarship and the escapist or cathartic demands of audienceship. There is no reason that factual accuracy and historicity should be dull and dry as dirt; the difference is made in the telling - the Canterbury pilgrims understood that. Their Tales were to be judged on the narrative balance of solace and sentence, their ability simultaneously to delight and instruct.

Lewis Lockwood makes two observations on this point, in his discussion of the film Immortal Beloved. He says that a "deep disdain, ill-concealed scorn, for mass audiences, is one of the bedrock assumptions in the minds of all too many film and television producers when they deal with so-called 'high cultural' topics" (195); his conviction suggests a reason for the ill treatment so many arts lives receive in the hands of filmmakers: the twits in the seats wouldn't know the difference.

Lockwood further itemizes what we (as the not-so-ignorant twits in the audience) seek in a filmed artist's life: "a sense of respect for the subject $[, \ldots]$ the capacity to make a gripping and interesting film $[, \ldots][$ and] an intelligent grappling with the elusive mysteries of artistic biography" (195-96). Lived lives are filled with the things movie audiences desire and expect from films: sex, fear, crisis, happiness, violence, folly, fulfilment, and loss. The choice of subject for a biographical film assigns value to that subject and that subject's way of being (think of Denzel Washington's five choices of historical figure to portray), and therefore the genre potentially has power to situate a historically-neglected individual in the public consciousness, to reassess the facts of a very public career, and to reconsider the devaluation of a way of being in the world.

Artists' lives are often neglected or concealed behind the statement made by their artistic production; in biographical films of these lives, the ironic danger is that the work of creation will be neglected in favour of the chance to look through the keyhole into the private and hopefully scandalous life of the artist; in the disappointing Wilde we don't even need the keyhole, because we get to be right in the room, a perfect example of the aforementioned disrespect for the subject. Since the visual and literary artist draws on the lived life as material for art, biographical films of artists are well advised to respect the work for its source value and for its potential to enact traits rather than incidents, personality rather than chronology.

In any life of an artist, the work has to be understood as central to that life; artists cannot leave their work at the office. Current trends in biographical film suggest broader contemporary social and cultural contexts from which and for which those films are made. Lockwood's 1997 article muses that "artistic biography in book form shows considerable signs of being a growth industry, and films cannot be far behind" (195), but he is predicting after the fact since the arts life was already being mined for its filmic value a decade or so prior.

George Custen's examination of the Studio-system biopic reveals that, during what he calls the first era, covering filmed lives made between 1927-1940 - in other words, between the World Wars - royalty and political leaders were figures of choice for filmmakers (Bio/Pics 84). The second wave of biopics, produced between 1941-1960 - from the time the United States became more actively engaged in World War II until the end of the studio system - producers privileged the performing artist as suitable subject. This ideological shift in subject no doubt combines a perceived loss of confidence in governments with an industry's self-congratulating, self-aggrandizing ego, and also speaks directly to escapist dreams of stardom and fandom, resulting in Custen's observation that "The entertainer rather than the political leader became the paradigmatic famous figure" (84).

While biographical treatments of those whose careers are necessarily public affairs have periodically abounded, whether they be athletes, politicians or singers, a variety of factors from our introspective age have come 
together and can be credited with the current resurgence of the genre in its third generation. This manifestation is dominated by characters drawn from among visual and literary artists, people whose solitary creative processes and intimacy with their various media offer something substantive, something particularly evident in but not confined to arts lives. The audience is a community of consumers which has been driven inward by the failure of its first two eras of biographical icons to satisfy or solve its problems. We no longer seek so much to escape from our own lives into the movies as to want something we can take from the movies into our own lives.

The Polish Nobel laureate Wislawa Szymborska observes in her 1996 Nobel lecture that biographical films generally are:

all quite naive and [don't] explain the strange mental state popularly known as inspiration, but at least there's something to look at and listen to. But poets are the worst. Their work is hopelessly unphotogenic. Someone sits at a table or lies on a sofa while staring motionless at a wall or ceiling. Once in a while this person writes down seven lines only to cross out one of them fifteen minutes later, and then another hour passes, during which nothing happens. ("Lecture")

But surely Beckett's Godot proves that nothing happening - twice, as the famous review goes - can hold an audience if the nothing exposes some of the agonies or joys of human existence. Ronald Bergan's discussion of the biopic concurs with Szymborska; he privileges the event (as some public action) as filmable: "The poems of a poet [he says], the novels of a novelist and the works of a composer are the most significant events in their lives and yet the creative act is rarely demonstrable" (21); Thomas Patrick Doherty believes that "the acts of reading and writing are, almost by definition, cinematically inert" (44). While it may be true that the creative act rarely has been demonstrated, this fact does not preclude the possibility of the act being demonstrated. Writing process, creative process in general, is not an event but a constant in the life of the artist.

Film has the capacity to suggest the passage of time, perhaps even a tedious expanse of time, without filming in real time to the point of tedium - James Cameron's film of sinking the Titanic notwithstanding. We can see the successful and entertaining representation of writing process in Total Eclipse (a life of Rimbaud and Verlaine) and Shakespeare in Love; and the dismal neglect of process and therefore failure of Wilde and Mrs. Parker and the Vicious Circle, in both of which writing is sublimated to scandal. The centrality of writing in the life of Reinaldo Arenas wisely is acknowledged and dramatized to powerful effect in Before Night Falls, where the writer's undeniable compulsion to write is made evident from boyhood (when he carves his words into trees) through his imprisonment (where he is shown smilingly content even in desperate circumstances when he is able to write).

It is a cumulative symptom of significant cultural change evident in films approximately of the last decade that three of five nominees in the category of Best Actor at the 2001 Academy Awards were nominated for biographical performances, specifically as literary and visual artists: Javier Bardem as Reinaldo Arenas in Before Night Falls, Geoffrey Rush as the Marquis de Sade in Quills, and Ed Harris as Jackson Pollock in Pollock; the Best Supporting Actress prize was awarded to Marcia Gay Harden for her performance as Lee Krasner in Pollock, and the winner of the Best Actress award was also cast in a biographical film, albeit not one concerned with the arts.

One third of the acting nominations at the 2002 event were for biographical performances: three for Iris for portrayals of British novelist Iris Murdoch and her husband John Bayley, two for Ali for those of Muhammad Ali and Howard Cosell, and two for A Beautiful Mind for those of John and Alicia Nash. The BioPic has made a resounding and successful return to the big screen, having gone away for a time to conquer the small one - to the point of having its own channel on cable. Biographical film has more to say to and about reality than so-called reality TV, which is so transparently fictional as to be ridiculous. Mimetic treatments of artistic lives as a type come together to theorize on the current cultural climate and make statements about the needs of the people in the seats.

It goes without saying that the outsider remains a powerfully romantic figure, but that figure, that re-formed example of rugged individualism, (through the auspices of the filmmaker) is taking up the pen and brush and chisel, rather than a weapon, is making art rather than violence, to make a space in which to exist. Joel 
Gordon suggests that "In the 1960s, the death of the studio system and prevailing social trends combined to transform the historical into anti-histories, the biopic into a celebration of anti-heroes" (64). No longer do we see so much that anyone can win regardless of the odds; these are not victorious underdog stories. Rather than rising above personal or national or global conditions and maybe even changing those conditions, new subjects find a way to live within conditions as they are, and therein lies the victory.

Jackson Pollock's newfound ability to move into the general popular imagination from the insular community of artists is made possible because of the very real appeal of his portrayal as a troubled and unstable man whose demons recede in direct correlation to his fascination with the physics of paint dribbling and swirling onto a horizontal canvas, who is most functional and able to cope when he is making art, which makes his world make some measure of sense to him.

This is fundamentally the same appeal of Ron Howard's A Beautiful Mind, which has about as much to do with math as Ali does with boxing. Julian Schnabel's Arenas is most at peace and happy when he writes, regardless of his surroundings; Sade writes even in the madhouse and the symbolic escape of his writing from imprisonment is a measure of freedom for him. Christopher Hampton's Carrington, an outsider on so many fronts including some unmentioned in the film, makes visual art of everything, all the time: frescoes in her house, doodles in her letters, woodcuts, drawings, painted canvasses.

Her drawings of Lytton Strachey's hands are such a gesture of love for him as could have been expressed no other way; to see them is to understand the tender and poignant devotion with which they were made, and to see her make them is to see her content in the peace of that moment which has a power to exclude temporarily the turmoil of her life. Artemisia Gentileschi, the first formally-trained European female painter, briefly escapes the constraints of her gender when her consciousness is consumed with visual art, with the male body as subject of art rather than object of desire; some of her painting also has been read as expression of murderous rage at a rapist, although interpretations of the documentary evidence of her life vary.

Movies such as Gentileschi's filmed life speak in opposition to Custen's observation that post-1960 biopics do "not seem to carry the same weight, nor perform the same cultural work" ("Mechanical" 130) as their predecessors. As the revitalized genre matures it is gaining weight and performing new cultural work. Along with what I perceive to be a cultural demand for private meaning and relevance experienced by the viewer of the filmed life, such as that provided by the reality of Alzheimer's Disease in Iris, there is also the work of valuation, legitimation, rehabilitation, of allowing women such as Carrington and Gentileschi to paint when painting has traditionally been considered a male art, of allowing Reinaldo Arenas to be gay in a medium which insisted that Cole Porter be straight, of allowing Sade's name to be mentioned in mixed company, of allowing Ali to be black and to be articulately political and to be heard all at the same time. In this way, too, the biographical film is reflective of what the market will allow, but that is not exclusive of what each member of that market needs.

This current movie audience is genuinely interested in the phenomenon of private art as articulate resolution of collective or shared issues. Since physical prowess in general, but certainly public action on a grand scale, is not available to everyone in the way that psychological processes are, the individual is drawn to the creative artist's life as more immediately relevant and more viable for indentificatory purposes, even though we do not all paint or compose or sculpt or write. In a time when the thoughts and feelings of anyone and everyone are socially valid and important, audiences arrive prepared to observe these ideal models acting out self-resolution through self-revelation.

If we seek no longer to understand the human condition in its entirety, because of its impossible permutations, still we can endeavour to comprehend our private experience of that condition, and what better place to look for guidance as to method than to those whose vocation it is to express their experience of the world in such a way that communicates to like-minded others. Audiences are no longer satisfied vicariously to lead soldiers into battle (although this obviously is informed by current events) or to bask in enraptured applause through observing the lives of generals or stars, because fame of that kind is no longer seen as a realistic solution to or escape from life's problems. And, anyway, fame no longer has the mystique it once had since anyone with a cell phone can be quoted on the evening news, and we find out Warhol was right when we watch TNN's Fame for 15. 
Fame as an achievement does not hold up in the face of close scrutiny, when previously protected reputations are thrown back to reveal human frailties; it makes more sense to look to those whose frailties and situations have been acknowledged from the start and incorporated in the artistic process, or at least in the process of life.

The more pressing need on an individual level is for an internal equilibrium which enables a limited understanding in a world with no universal answers, and so audiences instead seek strategies for achieving that psychological position: if we can't understand the world, at least perhaps we can understand ourselves and our place in it. Singing and dancing and hitting home runs or scoring touchdowns or leading charges have been proven not to change the world. I think further that those who previously dismissed the idea that art might have any active role in the world, now consider that it is art which provides a vital counterpoint to the external, animal, destructive aspects of human nature which depend on force and aggression as the means of achievement. The new icons and heroes are those who attempt to tolerate themselves, observe the world, and change it through that observation.

\section{References}

\section{Works Cited:}

Ali. Dir. Michael Mann. Columbia, 2001.

Artemisia. Dir. Agnes Merlet. Miramax Zoe, 1997.

Before Night Falls. Dir. Julian Schnabel. Grandview Pictures, 2000.

Bergan, Ronald. "Whatever Happened to the Biopic?" Films and Filming 346 (July 1983): 21-2.

A Beautiful Mind. Dir. Ron Howard. Universal, 2001.

Carrington. Dir. Christopher Hampton. Polygram Filmed Entertainment, 1995.

Custen, George F. Bio/Pics: How Hollywood Constructed Public History. New Brunswick, NJ: Rutgers, 1992.

. "The Mechanical Life in the Age of Human Reproduction: American Biopics, 1961-1980."

Biography: An Interdisciplinary Quarterly 23.1 (Winter 2000): 127-57.

Doherty, Thomas Patrick. "Malcolm X: In Print, On Screen." Biography: An Interdisciplinary Quarterly 23.1 (Winter 2000): 29-48.

The George McKenna Story. Dir. Eric Laneuville. Prism Entertainment, 1986.

Gordon, Joel. "Film, Fame, and Public Memory: Egyptian Biopics from Mustafa Kamil to Nasser 56." International Journal of Middle East Studies 31 (1999): 61-79.

The Hurricane. Dir. Norman Jewison. Universal, 1999.

Iris. Dir. Richard Eyre. BBC Films, 2001.

Lockwood, Lewis. "Film Biography as Travesty: Immortal Beloved and Beethoven." Musical Quarterly 81.2 (Summer 1997): 190-98.

Malcolm X. Dir. Spike Lee. 40 Acres and a Mule, 1992.

Mrs. Parker and the Vicious Circle. Dir. Alan Rudolph. Fine Line Features, 1994. 
Night and Day. Dir. Michael Curtiz. 1946. MGM/UA Home Video, 1993.

Pollock. Dir. Ed Harris. Sony Pictures Classics, 2000.

Quills. Dir. Philip Kaufman. Fox Searchlight, 2000.

Remember the Titans. Dir. Boaz Yakin. Buena Vista, 2000.

Shakespeare in Love. Dir. John Madden. Screenplay by Marc Norman and Tom Stoppard. Miramax Films, 1998.

Szymborska, Wislawa. "Nobel Lecture." Trans. Stanislaw Baranczak and Clare Cavanagh. Nobel e-Museum. http://www.nobel.se/.

Total Eclipse. Dir. Agnieszka Holland. New Line Cinema, 1995.

Wilde. Dir. Brian Gilbert. Sony Pictures Classics. 1998.

\section{Author Information}

A. Mary MURPHY recently completed her PhD with a dissertation on the theory and practice of life writing. She writes and publishes both criticism and poetry; she currently teaches at the University of Calgary and Alberta College of Art and Design. 